\title{
Effect of urine adulterants on commercial drug abuse screening test strip results
}

\author{
Ivana Rajšić1, Dragana Javorac ${ }^{2}$, Simona Tatović ${ }^{2}$, Aleksandra Repiće,3, Danijela Đukić-Ćosić2 \\ Snežana Đorđević ${ }^{4,5}$, Vera Lukić 6 , and Zorica Bulat ${ }^{2}$ \\ ${ }^{1}$ University of Novi Sad, Faculty of Medicine, Department of Pharmacology, Toxicology and Clinical Pharmacology, Novi Sad, Serbia \\ 2 University of Belgrade, Faculty of Pharmacy, Department of Toxicology "Akademik Danilo Soldatovic'", Belgrade, Serbia \\ ${ }^{3}$ Serbian Institute for Occupational Health "Dr Dragomir Karajović”, Belgrade, Serbia \\ ${ }^{4}$ Poison Control Centre, Military Medical Academy, Belgrade, Serbia \\ ${ }^{5}$ Medical Faculty, Military Medical Academy, University of Defence, Belgrade, Serbia \\ ${ }^{6}$ Institute of Forensic Medicine, Faculty of Medicine, University of Belgrade, Serbia
}

[Received in July 2019; Similarity Check in July 2019; Accepted in March 2020]

Immunochromatographic strips for urine drug screening tests (UDSTs) are common and very suitable for drug abuse monitoring, but are also highly susceptible to adulterants kept in the household, which can significantly alter test results. The aim of this study was to see how some of these common adulterants affect UDST results in practice and whether they can be detected by sample validity tests with $\mathrm{pH}$ and URIT $11 \mathrm{G}$ test strips. To this end we added household chemicals (acids, alkalis, oxidizing agents, surfactants, and miscellaneous substances) to urine samples positive for amphetamine, 3,4-methylenedioxymethamphetamine (MDMA), tetrahydrocannabinol, heroin, cocaine, or benzodiazepines (diazepam or alprazolam) and tested them with one-component immunochromatographic UDST strips. The UDST for cocaine resisted adulteration the most, while the cannabis test produced the most false negative results. The most potent adulterant that barely changed the physiological properties of urine specimens and therefore escaped adulteration detection was vinegar. Besides lemon juice, it produced the most false negative test results. In conclusion, some urine adulterants, such as vinegar, could pass urine specimen validity test and remain undetected by laboratory testing. Our findings raise concern about this issue of preventing urine tampering and call for better control at sampling, privacy concerns notwithstanding, and better sample validity tests.

KEY WORDS: false negative; household chemicals; immunochromatographic assay; lemon juice; URIT 11G; vinegar

The United Nations Office on Drugs and Crime (UNODC) World Drug Report for 2017 estimated that around 250 million people used an illicit drug at least once in 2015 (1). Based on the European Monitoring Centre for Drugs and Drug Addiction (EMCDDA) report for 2014 and 2017 , illicit drug use in Serbia is at similar levels as in other countries. The report indicated drug consumption as a major social and serious public health problem, especially in the younger population $(2,3)$. This is in accordance with the results of a school survey which found that $15.1 \%$ of Serbian secondary school students (15-16-yearolds) had tried psychoactive controlled substances at least once (4).

In response to widespread illicit drug consumption, on-site drug testing has become widely utilised because of its convenience and cost-efficiency. Urine drug screening (UDSTs) with immunochromatographic test strips is a rapid, non-invasive, inexpensive, and easy-to-handle on-site method that has found wide application in many fields, such as anti-doping control in sports, drug abuse rehabilitation

Corresponding author: Danijela Đukić-Ćosić, University of Belgrade Faculty of Pharmacy, Department of Toxicology "Akademik Danilo Soldatovič", Vojvode Stepe 450, 11221 Belgrade, Serbia

E-mail: danijela.djukic.cosic@pharmacy.bg.ac.rs monitoring, parental control, and forensic and clinical toxicology screening (5-11). UDSTs are particularly useful at the workplace for pre-employment screening or random on-the-job drug abuse testing $(11,12)$. UDSTs can be used by experienced laboratory personnel but are also available in commercial kits for general public and are usually sold in pharmacies with manufacturer instructions.

UDST devices are based on competition between a drug and a drug-dye conjugate for binding an anti-drug antibody immobilised on nitrocellulose membrane. If the urine sample is drug-free, the drug-dye conjugate and the immobilised anti-drug antibody create a coloured line indicating a negative test. However, if urine contains a drug above the cut-off level, the drug inhibits the drug-dye conjugate to bind to the antibody, and the result is positive (no line appears on the strip).

Their many advantages notwithstanding, UDSTs suffer of some shortcomings as well, including low accuracy and specificity. They can produce false positive results due to cross-reactivity with other non-targeted drugs of similar chemical structure or certain food ingredients. They can also produce false negative results if samples have been tampered with (11-14). 
According to literature, drug users tamper with samples to obtain negative results in three ways. The first is by consuming great amounts of fluid and/or taking diuretics to dilute urine to the point where a drug is no longer detectable (in vivo adulteration). The second is by replacing their own urine with a drug-free sample (synthetic or obtained from another person). However, when testing comes unannounced, drug consumers resort to simple addition of urine adulterating chemicals, in hope of obtaining a false negative drug test result (in vitro and in situ adulteration). There are many chemical substances that can produce this effect, including acids, alkalis, surfactants, and oxidising agents, and some of them have been designed to beat drug tests available on the market $(5,7,11,15-19)$.

For drug testing at the workplace there are two recommended ways to prevent adulteration or substitution of urine samples. If urine is collected in privacy [without (in)direct supervision by another person], this should take place in a toilet with water dyed in blue or turned off to prevent dilution (18). Alternatively, institutions and employers without this option resort to direct supervision (19). Samples can also be checked for temperature and integrity immediately after collection. In some cases, however, compliance with these recommendations is low, and urine collection goes unmonitored, which may lead to cheating at urine drug tests.

Because of the rise of narcotic consumption and drug abuse in early adolescence in Serbia, more and more parents are screen-testing their children with UDSTs at home (2, 3). Current commercially available immunochromatographic UDSTs can detect metabolites of the most common recreational drugs available on the Serbian black market such as cannabis, heroin, cocaine, amphetamine, or 3,4-methylenedioxymethamphetamine (MDMA) (20). At home, however, urine samples can easily be diluted or adulterated, so if there is any doubt, laboratory testing is the best choice $(21,22)$.

Households keep many readily-available chemicals that can adulterate urine samples, but little is known about how exactly they interfere with UDST results. Therefore, the aim of this study was to investigate the potential of the most popular urine adulterants (based on an Internet search) to turn UDST test results from positive to false negative for the most commonly abused psychoactive substances in the country/region. We also wanted to see whether $\mathrm{pH}$ and urine biochemical parameter test strips could help to check whether a sample has been changed by the tested adulterants.

\section{MATERIALS AND METHODS}

\section{Internet search for household adulterants}

We ran an inclusive Internet literature search with Google, Google Scholar, and PubMed search engines using the following key words/strings "urine adulteration", "tampering methods" and "false negative immunoassay" in English and Serbian. Information about urine tampering was also collected from various on-line drug forums. Internet search revealed a range of potential adulterants kept in the household, and we selected the most common acids, alkalis, surfactants, oxidising agents, additives, as well as one drug and one supplement to test their potential for changing positive strip test results into false negative (Table 1).

\section{Urine sampling}

Urine samples used in this study made part of those submitted to our toxicological laboratory for drug screening and were confirmed positive for one of the following substances: amphetamine, MDMA, tetrahydrocannabinol, heroin, cocaine, diazepam, or alprazolam (Table 2). The last two were selected as the most commonly abused benzodiazepines. Drug-free urine samples were prepared from pooled urine collected from three healthy donors. They were used as control in urine sample integrity tests.

For analysis we used the Waters Alliance ${ }^{\circledR}$ liquid chromatograph with a Waters Micromass ${ }^{\circledR} \mathrm{ZQ}^{\mathrm{TM}}$ mass spectrometer (Waters Corporation, Milford, MA, USA). All analytical methods have been validated for everyday use at laboratory accreditation. Diazepam and alprazolam were determined without previous hydrolysis and their concentrations are low, but the strip test was positive due higher concentrations of their metabolites (23).

\section{Immunochromatographic UDSTs}

We purchased the test strips that were available on the Serbian market at the time of the study from a wholesaler who supplies laboratories and pharmacies. For the detection of amphetamine, MDMA, cocaine, and benzodiazepines we used One Step Rapid ${ }^{\circledR}$ (Ameritek ${ }^{\circledR}$, Everett, WA, USA), while for tetrahydrocannabinol, morphine, heroin, and codeine we used AbuGnost ${ }^{\circledR}$ (Biognost ${ }^{\circledR}$, Zagreb, Croatia). All UDST kits were used according to manufacturer instructions. Two drops of urine were pipetted into the sample well of the test strip. The results were interpreted after $3-5 \mathrm{~min}$. These tests are qualitative, so a positive result means that the drug which is being screened for is most likely present in urine at a concentration above the cut-off level. Cut-off levels for MDMA, amphetamine, cocaine, benzodiazepine, tetrahydrocannabinol, and opiates (morphine, heroine, codeine) are $500 \mathrm{ng} / \mathrm{mL}, 1000 \mathrm{ng} / \mathrm{mL}$, $300 \mathrm{ng} / \mathrm{mL}, 300 \mathrm{ng} / \mathrm{mL}, 50 \mathrm{ng} / \mathrm{mL}$, and $300 \mathrm{ng} / \mathrm{mL}$, respectively. Manufacturers also warn about limited reliability of UDSTs if urine is adulterated. The test is invalid if there is no line in the control region, which indicates malfunctioning test strips and/or urine adulteration.

\section{Adulteration and testing}

Adulterants were added to the drug-positive urine samples $(1 \mathrm{~mL})$ in different amounts simulating real-life scenarios in which people do not have the equipment at 
Table 1 Adulterants considered for testing and the quantities used for those that passed urine appearance test

\begin{tabular}{|c|c|c|}
\hline Household adulterant & Form & $\begin{array}{c}\text { Quantity } \\
\text { used }\end{array}$ \\
\hline \multicolumn{3}{|l|}{ Acids } \\
\hline WC Sanitar $(9 \% \mathrm{HCl})$ & \multirow{3}{*}{ liquid } & $0.3 \mathrm{~mL}$ \\
\hline Vinegar (white distilled vinegar; $9 \%$ acetic acid) & & $0.2 \mathrm{~mL}$ \\
\hline Lemon juice & & $0.4 \mathrm{~mL}$ \\
\hline Citric acid & solid & $0.1 \mathrm{~g}$ \\
\hline \multicolumn{3}{|l|}{ Alkalis } \\
\hline Cevtok $(30 \% \mathrm{NaOH})$ & liquid & $0.1 \mathrm{~mL}$ \\
\hline \multicolumn{3}{|l|}{ Oxidizing agents } \\
\hline Varikina (bleach; $5 \% \mathrm{NaOCl}$ ) & liquid & $0.3 \mathrm{~mL}$ \\
\hline \multicolumn{3}{|l|}{ Surfactants } \\
\hline Asepsol ( $5 \%$ quaternary ammonium compounds, such as benzalkonium chloride) & & $0.2 \mathrm{~mL}$ \\
\hline $\begin{array}{l}V_{i s i n e}{ }^{\mathbb{P}} \text { eye drops (active substance: tetrahydrozoline-hydrochloride } 0.05 \% \mathrm{w} / \mathrm{v} \text {; non-medical } \\
\text { ingredients: benzalkonium-chloride, sodium chloride, boric acid, sodium borate, disodium EDTA) }\end{array}$ & liquid & $0.4 \mathrm{~mL}$ \\
\hline \multicolumn{3}{|l|}{ Liquid soap* } \\
\hline \multicolumn{3}{|l|}{ Household cleaning products Frosh, Aro and Skala* } \\
\hline \multicolumn{3}{|l|}{ Miscellaneous substances } \\
\hline Primosept GA ( $8 \%$ glutaraldehyde) & liquid & $0.4 \mathrm{~mL}$ \\
\hline Zn salts (tablets, supplements)* & solid & \\
\hline Nitrite and nitrate salts (meat product additives)* & solid & \\
\hline
\end{tabular}

* household chemicals that changed urine appearance and were not tested further for adulteration

hand to precisely measure the volume, yet try not to change urine's natural appearance to avoid being caught at cheating. We started with the lowest volume of $0.1 \mathrm{~mL}$, as we expected it would be practically impossible to add lower quantities than this in real-life conditions. The highest volume of adulterant added to urine was $40 \% \mathrm{vol} / \mathrm{vol}$, because larger amounts of liquids changed urine colour (it became too light not to notice) and urine would foam or smell of chemicals. For solid adulterants, the upper limit was determined by their solubility in urine. We tested only the samples that appeared unchanged. If the UDST result was unclear, that is, if the line that appeared was barely visible, the amount of adulterant was increased until a distinct result was obtained. The final quantities of adulterants that did not change the appearance of urine are given in Table 1. All tests were performed in duplicate.
Other adulterants were excluded from further study because they changed the appearance of urine even at the lowest quantities. These were liquid soap and household cleaning products Frosh, Aro, and Skala, and Zn salts, which come only in an unpractical tablet form, and changed urine appearance even when pulverised. Nitrite and nitrate salts were not tested because we could not find any product based on either in retail stores.

\section{Test strips for urine sample integrity check and adulterant detection}

Urine samples with and without adulterants and drugfree control urine were tested for indicators of adulteration with the URIT $11 \mathrm{G}$ urine reagent strips (Medical Electronic Co. Ltd., Guangxi, China) following manufacturer

Table 2 Urine drug (metabolite) concentrations and UDST results before adulteration with household chemicals

\begin{tabular}{lcc}
\hline Drug (metabolite) & $\begin{array}{c}\text { Urine concentration } \\
(\mathbf{m g} / \mathbf{L})\end{array}$ & UDST result \\
\hline MDMA & 0.83 & + \\
\hline Amphetamine & 2.28 & + \\
\hline Cocaine (benzoylecgonine) & 5.69 & + \\
\hline Diazepam & 0.077 & + \\
\hline Alprazolam & 0.065 & + \\
\hline Tetrahydrocannabinol & 112.2 & + \\
\hline (carboxy-tetrahydrocannabinol) & 0.23 & + \\
\hline Heroine (6-acetylmorphine) & & + \\
\hline
\end{tabular}


instructions. Considering that the URIT $11 \mathrm{G}$ strips have a narrower $\mathrm{pH}$ range ( $\mathrm{pH}$ 5-9), we also used $\mathrm{pH}$ test strips, whose range is $\mathrm{pH}$ 0-14 (Macherey-Nagel GmbH \& Co. KG, Düren, Germany).

\section{RESULTS}

Urine drug concentrations and UDST results obtained before adulteration are presented in Table 2. Table 3 shows how the tested adulterants affected UDST results. Vinegar (9\% acetic acid) turned nearly all UDST results false negative, with the exception of cocaine. Lemon juice followed suit in tampering, save for cocaine and opiates. Other adulterants were less efficient. Many of the adulterants invalidated the UDSTs, led by Cevtok $(30 \%$ $\mathrm{NaOH}$ ), which invalidated all of them.

Control drug-free and drug-positive urine samples tested with URIT $11 \mathrm{G}$ urine reagent strips and $\mathrm{pH}$ strips before adulteration showed similar findings suggesting maintained sample integrity, as expected (Table 4). After adulteration, however, URIT $11 \mathrm{G}$ urine reagent strips and $\mathrm{pH}$ strips revealed manipulation with some urine samples. WC Sanitar $(9 \% \mathrm{HCl})$ raised ascorbic acid levels compared to control and rendered the sample invalid due to compromised blood in urine values, plus it did not pass the $\mathrm{pH}$ strip test (see bolded values in Table 4$)$. Vinegar ( $9 \%$ acetic acid), lemon juice, and citric acid did change parameter levels of the URIT $11 \mathrm{G}$ test but not enough to reveal tampering. The $\mathrm{pH}$ test strip, however, did reveal tampering with lemon juice and citric acid. Cevtok $(30 \% \mathrm{NaOH})$ rendered URIT $11 \mathrm{G}$ test strips invalid on nearly all parameters and failed the $\mathrm{pH}$ strip test. Varikina (bleach; $5 \% \mathrm{NaOCl}$ ), in contrast, passed undetected, even though it did test positive for nitrite presence and raised urine blood cells count. Asepsol invalidated the sample over protein values. Primosept GA ( $8 \%$ glutaraldehyde) also rendered the sample invalid over high ketone values. Visine ${ }^{\circledR}$ eye drops, in turn, passed undetected.

\section{DISCUSSION}

To the best of our knowledge, until this study of ours, no one has reported research data about household chemicals interfering with urine drug test results. Many of the household chemicals used as adulterants in this study are available in other countries in the region and beyond, and our findings could be useful anywhere.

Urine collection for laboratory drug testing is still not completely regulated in Serbia, and no one knows how many urine samples have been collected without supervision. Even though there are no test strips to test urine for specific adulterants, URIT $11 \mathrm{G}$ and $\mathrm{pH}$ test did detect adulteration by five household chemicals. Both have their limitations, though. The $\mathrm{pH}$ test strips are limited to changes in $\mathrm{pH}$, whereas the URIT $11 \mathrm{G}$ test strips have a narrow $\mathrm{pH}$ range.

In terms of tampering, our study shows that the UDST for cannabinoids is susceptible to urine adulterants, as it yielded six false negative results. This is in line with earlier reports of immunoassay tests for cannabinoid detection (radioimmunoassay - RIA, enzyme immunoassay - EIA, and fluorescence polarisation immunoassay - FPIA) being the most susceptible to adulteration $(24,25)$. The UDST for amphetamine was also affected by adulterants (five invalid tests and three false negatives). In contrast, the UDST for cocaine was resistant to most adulterants (no false negative results), which has also been reported by Schwarzhoff and Cody (24). However, Asepsol, Primosept GA, and Cevtok did invalidate the test.

The most effective adulterants were acids and alkalis. They probably act through changes in $\mathrm{pH}$ and enable drugantibody binding (26). Vinegar was the most successful in producing false negative results, save for the cocaine test, and did not affect the URIT $11 \mathrm{G}$ test results enough to be detected. As it were, its finding of elevated ascorbic acid could be interpreted as a result of high vitamin C supplement intake. Its masking properties have already been reported for immunoassays such as FPIA and EIA for some drugs $(11,24-27)$. In contrast, the least efficient adulterant in our study were the Visine ${ }^{\circledR}$ eye drops, as they did not change

Table 3 UDST results obtained after adulteration of drug-positive urine samples with household chemicals

\begin{tabular}{|c|c|c|c|c|c|c|c|}
\hline \multirow{2}{*}{$\begin{array}{l}\text { Adulterating } \\
\text { agent }\end{array}$} & \multicolumn{7}{|c|}{ Urine positive for } \\
\hline & Opiates & Cannabinoids & Amphetamine & MDMA & Cocaine & Alprazolam & Diazepam \\
\hline WC Sanitar & Invalid & - & Invalid & Invalid & + & Invalid & Invalid \\
\hline Vinegar & - & - & - & - & + & - & - \\
\hline Lemon juice & + & - & - & - & + & - & - \\
\hline Citric acid & + & - & Invalid & + & + & Invalid & Invalid \\
\hline Cevtok & Invalid & Invalid & Invalid & Invalid & Invalid & Invalid & Invalid \\
\hline Varikina & - & - & - & + & + & + & + \\
\hline Asepsol & + & - & Invalid & Invalid & Invalid & Invalid & Invalid \\
\hline Primosept GA & + & + & Invalid & Invalid & Invalid & Invalid & Invalid \\
\hline Visine & + & + & + & + & + & + & + \\
\hline
\end{tabular}




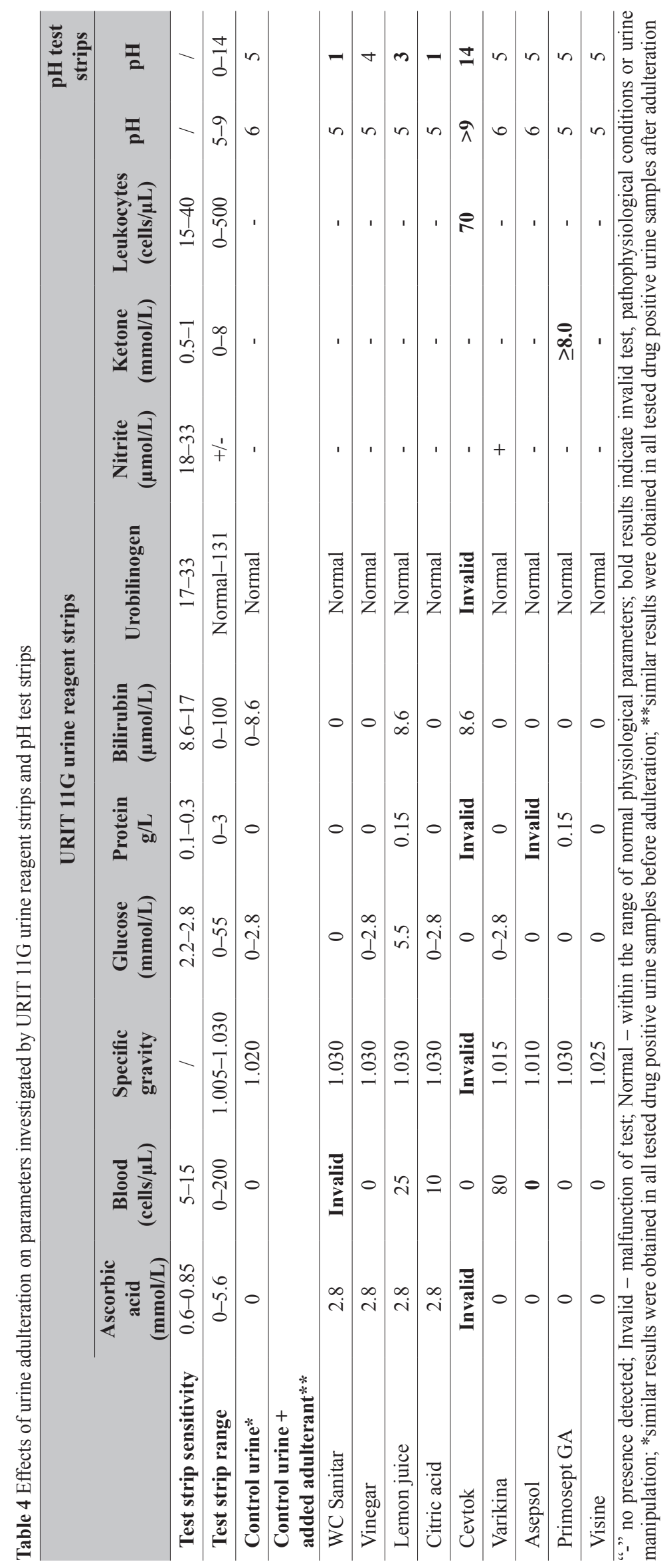


any of the original UDST findings, not even for cannabinoids, even though other reports say that it strongly interfered with immunoassays (FPIA, EIA, RIA) for the presence of cannabinoids $(11,25-27)$. To sum up, most of the investigated adulterants have the ability to change positive UDST strip results into false negative or render them invalid. In that respect vinegar and Asepsol stand out, as they can remain undetected even by experienced laboratory personnel.

In order to detect urine adulteration where test strips for urine adulterants are not available, urine samples should be checked not only with biochemical test strips such as URIT $11 \mathrm{G}$ and $\mathrm{pH}$ test strips but also visually and for warmth (if checking immediately after taking the sample), to see if they have been tampered with. Our study calls for more efficient screening methods for detecting sample manipulation. But maybe even more important is to develop drug screening methods, immunochromatographic or other, that will be more or even completely resistant to adulterants. In the meanwhile, urine should be collected by competent institutions in socalled "dry toilets" to ensure the integrity of the specimen and still protect the privacy of the person tested.

\section{REFERENCES}

1. United Nations Office on Drugs and Crime (UNODC), United Nations Office on Drugs and Crime, United Nations. World Drug Report 2017. Vienna: Division for Policy Analysis and Public Affairs; 2017.

2. Kilibarda B, Simić D, Baroš S, Brandić I. National Report on Drug Situation in Serbia, 2014 [displayed 18 March 2020]. Available at http://www.emcdda.europa.eu/system/files/ publications/805/National_Report_Serbia_2014_EN_483880. pdf

3. European Monitoring Centre for Drugs and Drug Addiction. Serbia National Drug Report, 2017 [displayed 3 January 2018]. Available at http://www.emcdda.europa.eu/system/files/ publications/4701/National\%20drug\%20report_Serbia.pdf_en

4. Ministry of Health of the Republic of Serbia, Institute of Public Health of Serbia “Dr Milan Jovanović-Batut", European School Project on Alcohol and other Drugs. European Survey on the use of Alcohol and Other Drugs among young people in Serbia, 2008 [displayed 18 March 2020]. Available at http://www.batut. org.rs/download/publikacije/ESPAD\%20eng\%202008.pdf

5. Standridge JB, Adams SM, Zotos AP. Urine drug screening: a valuable office procedure. Am Fam Physician 2010;81:635-40. PMID: 20187600

6. Manchikanti L, Atluri S, Trescot AM, Giordano J. Monitoring opioid adherence in chronic pain patients: tools, techniques, and utility. Pain Physician 2008;11(Suppl 2):S155-80. PMID: 18443638

7. Schulberg M, Gerostamoulos D. Urinary drug screening. Aust Prescr 2013;36:62-4. doi: 10.18773/austprescr.2013.051

8. Tominaga M, Michiue T, Maeda $\mathrm{H}$. Evaluation of the on-site immunoassay drug-screening device Triage-TOX in routine forensic autopsy. Leg Med (Tokyo) 2015;17:499-502. doi: 10.1016/j.legalmed.2015.10.007
9. Moriya F. Urine levels of drugs for which Triage DOA screening was positive. Leg Med (Tokyo) 2009;11(Suppl 1):S434-6. doi: 10.1016/j.legalmed.2009.01.090

10. Gomolka E. Immunoassay in toxicology diagnosis. In: Abuelzein E, editor. Trends in immunolabelled and related techniques. Rijeka: InTech; 2012. p. 67-82.

11. Jaffee WB, Trucco E, Levy S, Weiss RD. Is this urine really negative? A systematic review of tampering methods in urine drug screening and testing. J Subst Abuse Treat 2007;33:33-42. doi: 10.1016/j.jsat.2006.11.008

12. Zimbardi G. Workplace substance use, the risk of occupational injury, and testing [dissertation]. Pittsburgh: University of Pittsburgh; 2005.

13. Riahi-Zanjani B. False positive and false negative results in urine drug screening tests: tampering methods and specimen integrity tests. PhOL 2014;1:102-8.

14. Moeller KE, Lee KC, Kissack JC. Urine drug screening: practical guide for clinicians. Mayo Clin Proc 2008;83:66-76. doi: 10.4065/83.1.66

15. Schütz H, Erdmann F, Verhoff MA, Weiler G. Pitfalls of toxicological analysis. Leg Med (Tokyo) 2003;5(Suppl 1):S619. doi: 10.1016/s1344-6223(02)00084-6

16. Cone EJ, Lange R, Darwin WD. In vivo adulteration: excess fluid ingestion causes false-negative marijuana and cocaine urine test tesults. J Anal Toxicol 1998;22:460-73. doi: 10.1093/ $\mathrm{jat} / 22.6 .460$

17. Conel EJ, Caplan YH, Moser F, Robert T, Shelby MK, Black DL. Normalization of urinary drug concentrations with specific gravity and creatinine. JAnal Toxicol 2009;33:1-7. doi: 10.1093/jat/33.1.1

18. Dasgupta A. The effects of adulterants and selected ingested compounds on drugs-of-abuse testing in urine. Am J Clin Pathol 2007;128:491-503. doi: 10.1309/FQY06F8XKTQPM149

19. USA Federal Register. Mandatory guidelines for federal workplace drug testing programs using urine specimens, Subpart $\mathrm{H}$ - Urine Specimen Collection Procedure. Federal Register Vol. 80, No. 94, 2015.

20. Medicines and Medical Devices Agency of Serbia [displayed 18 March 2020]. Available at https://www.alims.gov.rs/eng/ medical-devices/

21. Rahdert E, Czechowicz D. Adolescent Drug abuse: Clinical Assessment and Therapeutic Interventions. NIDA Research Monograph 156. Rockville: National Institute on Drug Abuse Research; 1995.

22. Washio Y, Fairfax-Columbo J, Ball E, Cassey H, Arria A, Bresani E. A review of guidelines on home drug testing websites for parents. J Addict Med 2014;8:258-63. doi: 10.1097/ ADM.0000000000000042

23. Roškar R, Sollner Dolenc M. Determination of benzodiazepines in urine via benzophenone derivatives using liquid chromatographytandem mass spectrometry. Arh Hig Rada Toksikol 2010;61:3818. doi: 10.2478/10004-1254-61-2010-2058

24. Schwarzhoff R, Cody J. The effects of adulterating agents on FPIA analysis of urine for drugs of abuse. J Anal Toxicol 1993;17:14-7. doi: 10.1093/jat/17.1.14

25. Cody J, Schwarzhoff R. Impact on adulterants on RIA analysis of urine for drugs of abuse. J Anal Toxicol 1989;13:277-84. doi: 10.1093/jat/13.5.277

26. Mikkelsen S, Ash O. Adulterants causing false negatives in illicit drug testing. Clin Chem 1988;34:2333-6. PMID: 3052928

27. Warner A. Interference of common household chemicals in immunoassay methods for drugs of abuse. Clin Chem 1989;35:648-51. PMID: 2539273 


\section{Utjecaj adulteranata u mokraći na nalaze komercijalnih testnih traka za otkrivanje zloporabe droga}

Preliminarna analiza prisutnosti psihoaktivnih tvari u mokraći pomoću imunokromatografskih testnih traka (UDST) našla je primjenu u mnogim područjima. Iako vrlo prikladne u kontroli zloporabe droga, testne su trake iznimno osjetljive na sredstva za patvorenje (adulterante) kao što su kućne kemikalije, što može značajno promijeniti rezultate testa. Cilj ovoga istraživanja bio je ispitati potencijal uobičajeno korištenih adulteranata kada je riječ o utjecaju na rezultate probira na prisutnost psihoaktivnih tvari u mokraći uporabom UDST-a. Ispitivane kemikalije (kiseline, lužine, oksidirajuća sredstva, površinski aktivne tvari i druge) dodane su uzorcima urina u kojima je, tekućinskom kromatografijom - masenom spektrometrijom (LC-MS) prethodno potvrđena prisutnost amfetamina, 3,4-metilendioksimetamfetaina (MDMA), tetrahidrokanabinola, heroina i kokaina benzodiazepina (diazepam ili alprazolam). U ispitivanju su korištene jednokomponentne imunokromatografske testne trake. Manipulacija uzorcima urina provjeravala se pomoću $\mathrm{pH}$ traka, kao i biokemijskih testnih traka za semikvantitativno određivanje koncentracija endogenih tvari i specifične težine uzoraka urina pomoću testnih traka URIT 11G. Rezultati ovoga ispitivanja pokazali su da je test za detekciju kokaina u urinu najmanje osjetljiv na utjecaj ispitivanih adulteranata, a test za detekciju kanabinoida najosjetljiviji, posebice u pogledu lažno negativnih rezultata. Najsnažniji adulterant koji je utjecao na rezultate testa a nije promijenio fiziološke parametre urina je alkoholni ocat. Osim soka od limuna, alkoholni ocat dodan u urin proizveo je najveći broj negativnih ishoda testiranja. Može se zaključiti da značajan broj adulteranata utječe na rezultate testa i da je moguće da neki od njih, poput alkoholnoga octa, mogu proći neopaženo pri kontroli valjanosti uzorka. Ovi nalazi upozoravaju na važnost strogo kontroliranog okruženja za uzorkovanje urina kako bi se spriječile manipulacije.

KLJUČNE RIJEČI: imunokromatografski test; kućne kemikalije; lažno negativni rezultati; limunski sok; ocat; URIT 11G 